ARTIKEL PENELITIAN

\title{
Hubungan kadar insulin-like growth factor 1 serum maternal dengan berat badan dan panjang badan bayi baru lahir pada ibu hamil KEK
}

\author{
Yulia Fatma Nasution ${ }^{1}$, Nur Indrawaty Lipoeto², Yulizawati ${ }^{3}$ \\ 1. Program Studi Pascasarjana Ilmu Kebidanan, Fakultas Kedokteran, Universitas Andalas; 2. Bagian \\ IImu Gizi, Fakultas Kedokteran, Universitas Andalas; 3. Bagian Kebidanan, Fakultas Kedokteran, \\ Universitas Andalas
}

Korespondensi: Yulia Fatma Nasution; e-mail: yuliafatmanst@gmail.com

\begin{abstract}
Abstrak
Tujuan: Untuk mengetahui hubungan kadar IGF-1 dengan berat badan dan panjang badan bayi baru lahir pada ibu hamil dengan kekurangan energi kronik. Metode: Penelitian ini dilakukan dii Puskesmas Belimbing dan Puskesmas Lubuk Buaya Kota Padang pada bulan Oktober sampai Desember 2018. Penelitian ini menggunakan metode analitik korelatif dengan desain potong lintang. Analisis data menggunakan uji korelasi Spearman dengan nilai $p<0,05$ dianggap bermakna secara statistik. Sampel penelitian sebanyak 40 orang ibu hamil dengan kekurangan energi kronik. Hasil: Hasil penelitian menunjukkan terdapat hubungan yang bermakna antara kadar IGF-1 serum maternal dengan berat badan lahir bayi $(p=0,001 ; r=0,493)$, namun tidak terdapat hubungan yang bermakna antara kadar IGF1 serum maternal dengan panjang badan lahir bayi $(p=0,105 ; r=0,260)$. Simpulan: Terdapat hubungan kadar IGF-1 serum maternal dengan berat badan lahir bayi.
\end{abstract}

Kata kunci: kekurangan energi kronik; IGF-1; berat badan lahir; panjang badan lahir

\section{Abstract}

Objectives: To find the correlation of IGF-1 levels with the weigh and length of the newborn infants in pregnant women with chronic energy deficiency. Methods: This research was conducted in community health Center of Belimbing and Lubuk Buaya from October until December 2018. The research was a correlative analytical study with cross sectional design. The data were analyzed using the Spearman Correlation test with a value of $p<0,05$ considered as statically meaningful. Sample of this study were 40 pregnant women with the chronic energy deficiency. Results: At the bivariate test there was a significant correlation between the levels of IGF-1 serum maternal with a birth weight with a value of $p=0.001$ and $r=0.493$, but there was no significant correlation between the levels of IGF-1 serum maternal with the baby's birth length with a value of $p=0.105$ and $r=0.260$. Conclusion: There is a significant correlation between maternal serum IGF-1 levels with a birth weight.

Keywords: chronic energy deficiency; IGF-1; body weight of newborn; body length of newborn 


\section{PENDAHULUAN}

Kehamilan merupakan masa terpenting untuk pertumbuhan janin. Salah satu faktor yang mempengaruhi keberhasilan suatu kehamilan adalah status gizi ibu sebelum dan selama kehamilan. ${ }^{1}$ Permasalahan yang terjadi pada kehamilan yang berhubungan dengan status gizi dan intake energi yang menyimpang selama kehamilan salah satunya adalah kekurangan energi kronik. ${ }^{2}$ Kurang Energi Kronik (KEK) adalah keadaan dimana ibu hamil menderita kekurangan makanan atau malnutrisi yang berlangsung lama (kronik) dengan timbulnya berbagai gangguan kesehatan pada ibu hamil. ${ }^{3}$

Berdasarkan data Riset Kesehatan Dasar (2013), diketahui bahwa prevalensi Wanita Usia Subur yang menderita KEK di Indonesia mencapai 24,2\%. Sedangkan jumlah wanita usia subur di Provinsi Sumatera Barat yang mengalami KEK sebanyak 20,9\%. ${ }^{4}$ Di Kota Padang kejadian KEK terus meningkat yakni pada tahun 2013 sebesar 4,4\%, tahun 2014 sebesar 4,9\% hingga pada tahun 2017 sebesar $5,3 \% .^{5}$

Ibu hamil dengan KEK berisiko melahirkan bayi dengan berat badan lahir rendah (BBLR) dan bayi pendek. ${ }^{6}$ Bayi pendek akan tumbuh menjadi dewasa yang pendek (stunting) dan berisiko tinggi mengalami gangguan kognitif dan neurologis. ${ }^{7}$ Selain itu bayi dengan berat badan lahir rendah lebih berisiko untuk menderita penyakit kardiovaskuler dan diabetes melitus tipe 2 pada saat dewasa. ${ }^{8}$
Prevalensi kelahiran bayi dengan berat badan lahir rendah (BBLR) dan Balita pendek di Indonesia berdasarkan Riset Kesehatan Dasar tahun (2013), dilaporkan masing-masing sebesar $10,2 \%$ dan $37,2 \%$. Sedangkan angka BBLR dan Balita pendek di Provinsi Sumatera Barat masing-masing sebesar 7,3\% dan 40\%. ${ }^{9}$ Angka kejadian BBLR di kota padang pada tahun 2013 dilaporkan sebesar $1 \%$ dan meningkat di tahun 2014 menjadi 1,74\%. ${ }^{4}$

Kekurangan energi kronik selama kehamilan, berkaitan dengan beberapa efek samping pada sistem endokrin, antara lain berkurangnya konsentrasi Insulin-like Growth Factor 1 (IGF-1) yang bersirkulasi dalam tubuh ibu. ${ }^{10}$ Insulin-like Growth Factor 1 (IGF-1) merupakan hormon polipeptida yang diproduksi terutama oleh hati dalam merespons stimulus hormon pertumbuhan $(\mathrm{GH}){ }^{11}$

IGF-1 merangsang sintesis $1,25-(\mathrm{OH}) 2 \mathrm{D}$ di ginjal untuk meningkatkan penyerapan kalsium dan fosfat dalam tubuh ibu yang selanjutnya akan di kirimkan ke janin melalui plasenta untuk proses pertumbuhan dan pembentukan tulang janin. ${ }^{12}$

IGF-1 juga memberikan sinyal positif pada Mammalian Target of Rapamycin (mTOR) yang merupakan sensor nutrien plasenta di sel trofoblast. $^{13}$ IGF-1 merangsang beberapa transporter nutrien di plasenta, di antaranya transporter glukosa, protein dan asam lemak yang sangat dibutuhkan untuk proses pertumbuhan dan perkembangan janin selama kehamilan. ${ }^{14}$ 
IGF-1 merupakan salah satu regulator utama dalam pertumbuhan janin melalui efek terhadap metabolisme tubuh ibu dan stimulasi pada plasenta. ${ }^{13}$ Apabila konsentrasi IGF-1 berkurang dapat mengakibatkan transpor nutrien dari ibu ke janin terganggu sehingga pertumbuhan dan perkembangan janin menjadi tidak optimal. ${ }^{15}$

Beberapa studi sebelumnya telah melaporkan bahwa kadar IGF-1 serum maternal dapat mempengaruhi berat badan bayi yang dilahirkan ${ }^{16}$, namun masih terdapat kontroversi dan perdebatan terkait peran IGF-1 terhadap pertumbuhan janin, hal ini dikarenakan IGF-1 tidak dapat melewati plasenta dan pengaruh IGF-1 kemungkinan besar melalui stimulus fungsi plasenta dan peningkatan suplai nutrisi bagi janin. ${ }^{17}$

Berdasarkan studi pendahuluan yang peneliti lakukan didapatkan informasi bahwa dai 22 puskesmas yang terdapat di Kota Padang, Puskesmas Belimbing dan Puskesmas Lubuk Buaya menjadi penyumbang tertinggi angka kejadian KEK dengan masing-masing angka kejadian sebesar $19,4 \%$ dan $11,7 \% .^{18}$

Melihat angka kejadian KEK dan BBLR yang terus meningkat dan banyaknya manfaat yang diberikan IGF-1 serum maternal pada pertumbuhan dan perkembangan janin selama kehamilan, maka peneliti tertarik untuk meneliti hubungan kadar IGF-1 serum maternal dengan berat badan dan panjang badan bayi baru lahir pada ibu hamil KEK di wilayah kerja Puskesmas Belimbing dan Puskesmas Lubuk Buaya tahun 2018.

\section{METODE}

Penelitian ini merupakan penelitian analitik korelatif dengan pendekatan crosssectional, dengan tujuan untuk melihat hubungan kadar IGF-1 serum maternal dengan berat badan dan panjang badan bayi baru lahir pada ibu hamil KEK di wilayah kerja Puskesmas Belimbing dan Puskesmas Lubuk Buaya Kota Padang.

Pemeriksaan kadar IGF-1 serum maternal dilakukan di Laboratorium Biomedik Fakultas Kedokteran Universitas Andalas. Penelitian dilakukan dari bulan Oktober sampai Desember 2018.

Populasi dalam penelitian ini adalah seluruh ibu hamil (37-42 minggu) dengan kekurangan energi kronik yang berada di wilayah kerja Puskesmas Belimbing dan Puskesmas Lubuk Buaya kota Padang. Besar sampel penelitian ini adalah 40 sampel. Pengambilan sampel dilakukan dengan cara consecutive sampling yaitu semua pasien yang memenuhi kriteria inklusi dan eksklusi dimasukkan dalam penelitian sampai besar sampel yang dibutuhkan terpenuhi.

Penelitian ini telah mendapatkan persetujuan etik dari Komite Etik Penelitian Fakultas Kedokteran Universitas Andalas No.552/KEP/FK/2018. Penelitian dilakukan dengan pengambilan $2 \mathrm{ml}$ darah ibu, sampel darah di sentrifugasi kemudian di ambil serumnya untuk dilakukan pemeriksaan kadar IGF-1 di Laboratorium Biomedik Fakultas Kedokteran Universitas 
Andalas dengan metode ELISA. Pemeriksaan berat badan dan panjang badan dilakukan setelah bayi lahir dalam waktu $<6$ jam.

Dilakukan uji normalitas data menggunakan uji Shapiro-wilk (sampel <50). Uji hipotesis diakukan dengan uji korelasi Spearman. Koefisien korelasi dinyatakan dengan $r$ dan kemaknaan jika nilai $p<0,05$. Kekuatan korelasi secara statistik dinilai dan diinterpretasikan dengan nilai $r=0,0-<0,2$, sangat lemah; $r=0,2-<0,4$, lemah; $r=0,4-<0,6$, sedang; $r=0,6-<0,8$, kuat; $r=0,8-1,0$ sangat kuat. ${ }^{19}$ Uji Mann-Whitney dilakukan untuk melihat perbedaan kadar IGF-1 maternal yang melahirkan bayi dengan berat $\leq 2500$ gram dan >2500 gram.

\section{HASIL DAN PEMBAHASAN}

Karakteristik subjek penelitian dilihat dari umur ibu, usia kehamilan, paritas, pertambahan berat badan ibu selama hamil, tinggi badan ibu, indeks massa tubuh, dan kadar hemoglobin.

Tabel 1. Karakteristik Ibu Hamil

\begin{tabular}{lcccc}
\hline \multicolumn{1}{c}{ Karakteristik } & $\mathrm{n}$ & Median & Mean \pm SD & Min-Maks \\
\hline Umur (thn) & 40 & 28 & $28,83 \pm 3,86$ & $22-35$ \\
Usia Kehamilan & 40 & 39 & $39,15 \pm 0,86$ & $38-41$ \\
Paritas & 40 & 2 & $1,83 \pm 0,95$ & $0-3$ \\
Pertambahan BB Ibu & 40 & 10 & $10,28 \pm 1,28$ & $8-12$ \\
TB Ibu & 40 & 155 & $156,57 \pm 4,73$ & $148-166$ \\
IMT $\left(\mathrm{kg} / \mathrm{m}^{2}\right)$ & 40 & 17,5 & $17,62 \pm 0,45$ & $17-18,3$ \\
\hline
\end{tabular}

Tabel 2. Rerata IGF-1, Berat Badan, dan Panjang Badan Bayi Baru Lahir

\begin{tabular}{lcccc}
\hline \multicolumn{1}{c}{ Variabel } & $\mathrm{n}$ & Median & Mean \pm SD & Min-Maks \\
\hline Kadar IGF-1 $(\mathrm{ng} / \mathrm{mL})$ & 40 & 151,44 & $153,47 \pm 27,68$ & $110,92-198,72$ \\
Berat Badan Lahir $(\mathrm{gram})$ & 40 & 2800 & $2780 \pm 222,11$ & $2300-3100$ \\
Panjang Badan Lahir $(\mathrm{cm})$ & 40 & 49 & $48,78 \pm 1,40$ & $46-51$ \\
\hline
\end{tabular}

Hasil analisis univariat pada Tabel 1 menunjukkan bahwa rata-rata umur ibu adalah 28,83 $\pm 3,86$ dengan nilai minimal 22 tahun dan maksimal 35 tahun, rata-rata usia kehamilan ibu adalah 39,15 $\pm 0,86$ dengan nilai minimal 38 minggu dan maksimal 41 minggu, rata-rata paritas ibu adalah $1,83 \pm 0,95$, dengan nilai minimal 0 anak dan maksimal 3 anak, rata-rata pertambahan berat badan ibu adalah $10,28 \pm 1,28$ dengan nilai minimal $8 \mathrm{~kg}$ dan maksimal $12 \mathrm{~kg}$, rata-rata, tinggi badan ibu adalah $156,57 \pm 4,73$ dengan nilai minimal
$148 \mathrm{~cm}$ dan maksimal $166 \mathrm{~cm}$, rata-rata IMT ibu adalah 17,62 $\pm 0,45$ dengan nilai minimal $17 \mathrm{~kg} / \mathrm{m}^{2}$ dan maksimal 18,3 $\mathrm{kg} / \mathrm{m}^{2}$, rata-rata kadar $\mathrm{Hb}$ ibu adalah $11,29 \pm 0,28$ dengan nilai minimal $11 \mathrm{~g} / \mathrm{dL}$ dan maksimal 12,3 g/dL.

Pada tabel 2, menunjukkan bahwa median kadar IGF-1 ibu hamil KEK adalah 151,44 $\mathrm{ng} / \mathrm{mL}$ dengan nilai rata-rata $153,47 \pm 27,68$, median berat badan lahir bayi adalah 2.780 gram dengan nilai ratarata $2780 \pm 222$, dan median panjang badan 
lahir bayi adalah $49 \mathrm{~cm}$ dengan nilai ratarata $48,78 \pm 1,40$.

Analisis bivariat dengan menggunakan korelasi Spearman, dapat dilihat pada gambar 1 Scatter Plot yang menunjukkan bahwa terdapat hubungan positif yang signifikan dengan kekuatan sedang antara kadar IGF-1 serum maternal dengan berat badan lahir bayi $(p=0,001 ; r=0,493)$. Dapat dilihat pada gambar bahwa nilai $R^{2}=0,241$ yang artinya $24,1 \%$ kadar IGF-1 mempengaruhi berat badan bayi baru lahir sedangkan $75,9 \%$ lagi dipengaruhi oleh faktor lain.

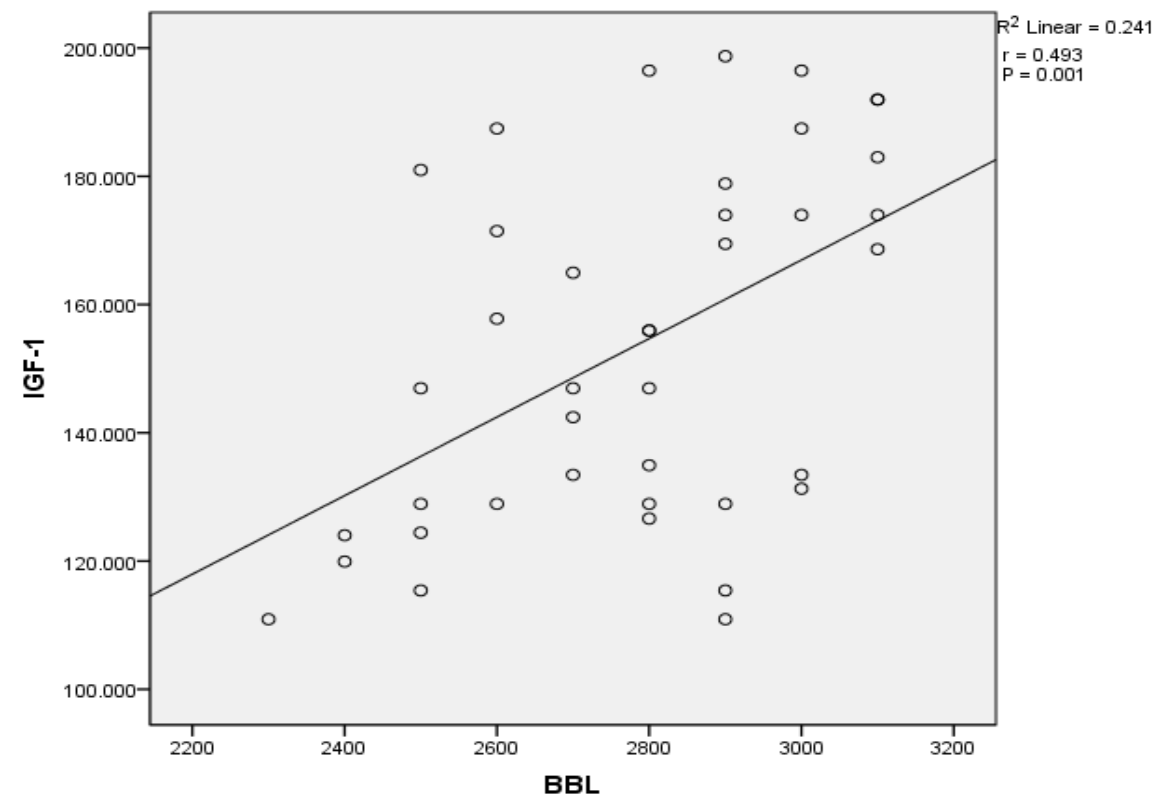

Gambar 1. Scatter Plot Hubungan Kadar IGF-1 dengan Berat Badan Lahir Bayi

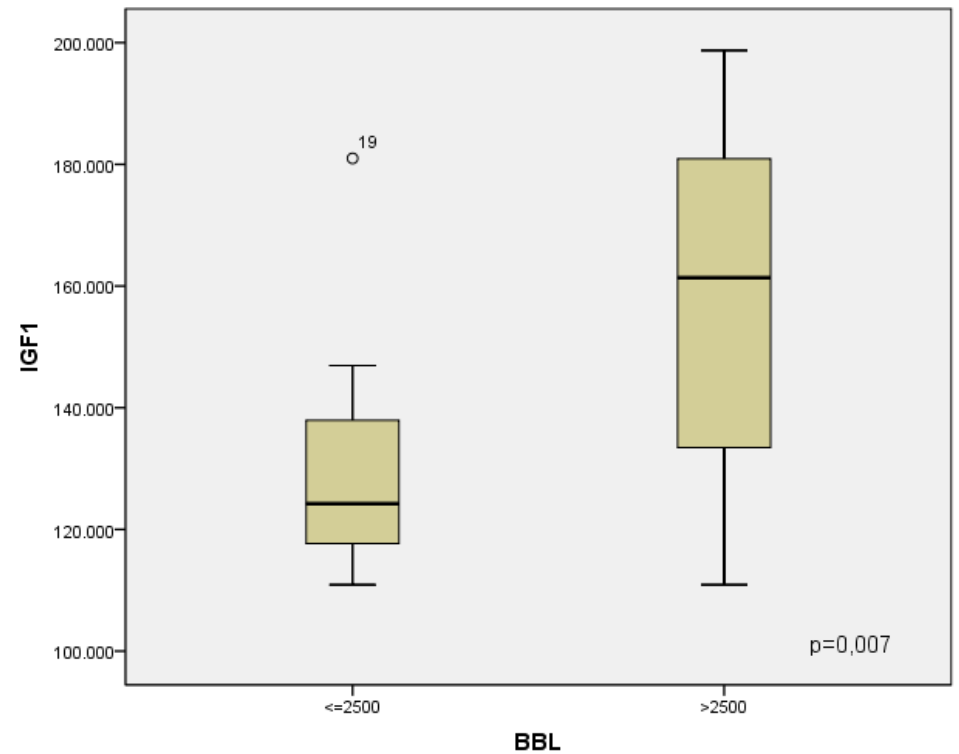

Gambar 2. Box Plot Pebedaan Kadar IGF-1 antara Ibu dengan Bayi $\leq 2500$ gram dan Bayi $>2500$ gram 
Gambar 2 pada Box Plot menunjukkan bahwa terdapat perbedaan kadar IGF-1 serum maternal antara ibu yang melahirkan bayi dengan berat $\leq 2.500$ gram dan ibu yang melahirkan bayi dengan berat $>2.500$ gram $(p=0,007)$.

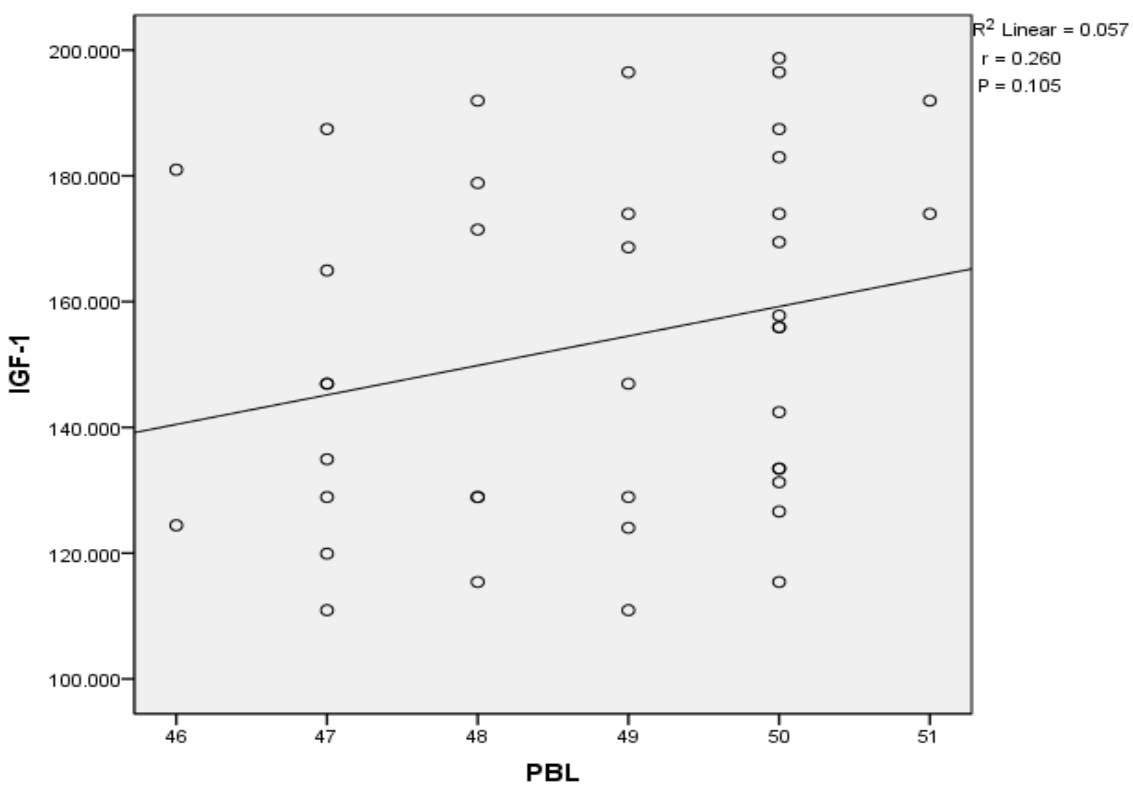

Gambar 3. Scatter Plot Hubungan Kadar IGF-1 dengan Panjang Badan Lahir Bayi

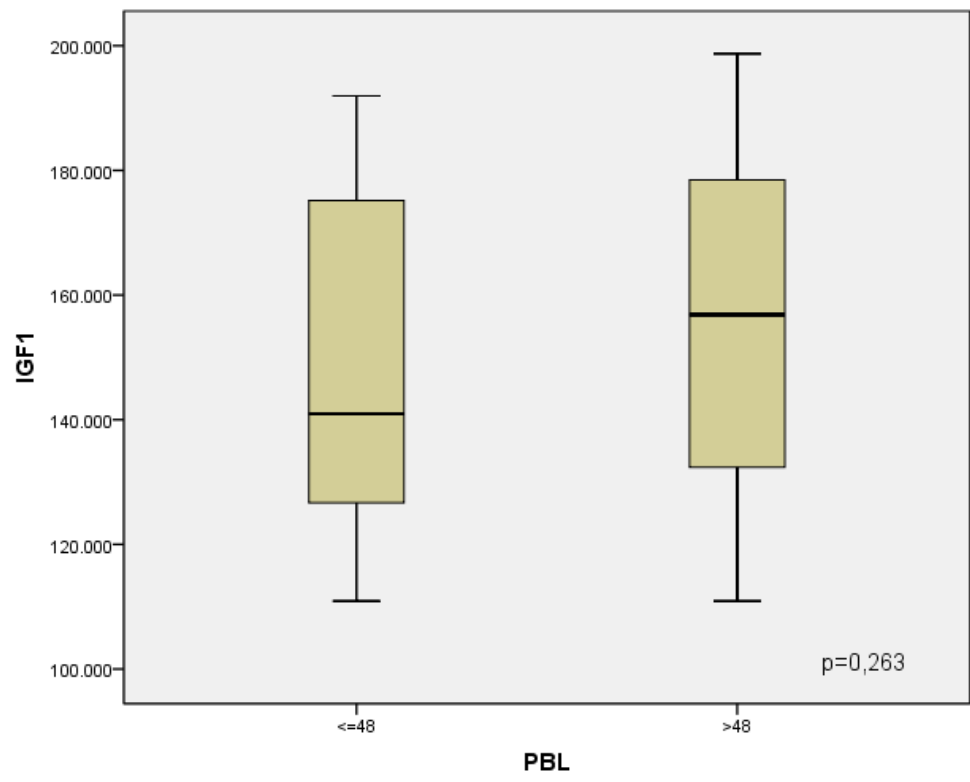

Gambar 4. Box Plot Perbedaan Kadar IGF-1 antara Ibu dengan Bayi $\leq 48 \mathrm{~cm}$ dan Bayi $>48 \mathrm{~cm}$

Scatter Plot pada Gambar 3 menunjukkan bahwa terdapat hubungan positif yang lemah tetapi tidak signifikan antara kadar IGF-1 serum maternal dengan panjang badan lahir bayi ( $p=0,105 ; r=0,260)$. Didapatkan juga dari gambar di atas bahwa nilai $\mathrm{R}^{2}=0,057$ yang artinya $5,7 \%$ kadar IGF1 mempengaruhi panjang badan bayi baru 
lahir sedangkan 94,3\% lagi dipengaruhi oleh faktor lain.

Gambar 4 menunjukkan bahwa tidak terdapat perbedaan kadar IGF-1 serum maternal antara ibu yang melahirkan bayi dengan panjang badan $\leq 48 \mathrm{~cm}$ dan ibu yang melahirkan bayi dengan panjang badan $>48 \mathrm{~cm}(p=0,263)$.

Korelasi IGF-1 Serum Maternal dengan Berat Badan Lahir Bayi

Hasil uji statistik menunjukkan bahwa terdapat hubungan positif yang signifikan dengan kekuatan sedang antara kadar IGF1 serum maternal dengan berat badan lahir bayi ( $p=0,001 ; r=0,493$ dan $\left.R^{2}=0,241\right)$, dengan demikian dapat diartikan semakin tinggi kadar IGF-1 maternal, semakin besar berat badan bayi yang dilahirkan, dimana IGF-1 maternal berkontribusi sebesar $24,1 \%$ terhadap berat badan lahir, sedangkan $75,1 \%$ sisanya dipengaruhi oleh faktor lain yang tidak diteliti.

Hasil penelitian ini sejalan dengan penelitian Lima dkk. (2004) yang mendapatkan adanya hubungan antara kadar IGF-1 maternal dengan berat badan lahir dengan nilai $r=0,37(p<0,05)$. Desain penelitian yang digunakan adalah casecontrol dengan dua kelompok sampel, ibu hamil yang sehat dengan berat janin $<2.500$ gram dan ibu hamil yang sehat dengan berat janin $\geq 2.500$ gram. ${ }^{17}$

Hasil penelitian serupa juga di laporkan oleh Karamizadeh dkk. (2008), yang mendapatkan korelasi IGF-1 maternal dengan berat lahir dengan nilai $r=0,32$ $(p<0,05)$. Pada penelitian, Karamizadeh membagi sampelnya ke dalam dua kelompok yaitu Small for Gestational Age (SGA) dan Appropriate for Gestational Age (AGA), dengan pemeriksaan IGF-1 dilakukan menggunakan metode Immunoradiometric Assay (IRMA). ${ }^{16}$

Hasil yang berbeda dilaporkan oleh Asvold dkk. (2011) di Norwegia dan Chellakooty dkk. (2004) di Denmark yang menemukan tidak adanya hubungan antara kadar IGF-1 maternal dengan pertumbuhan janin dan berat badan lahir. Perbedaan metode penelitian dan karakteristik responden diduga mempengaruhi hasil penelitian ini. $^{20,21}$

IGF-1 maternal dapat mempengaruhi pertumbuhan janin melalui aksi stimulasi aktivitas transporter nutrien di plasenta. ${ }^{22}$ Plasenta sangat berperan dalam pertumbuhan dan perkembangan janin sehingga gangguan dalam fungsi plasenta dapat menyebabkan overgrowth ataupun IUGR (Intrauterin Growth Restriction). ${ }^{23}$

Hormon ibu seperti insulin, IGF-1 dan persinyalan mTOR di trofoblas merupakan regulator utama transpor asam amino di plasenta, dimana asam amino sangat dibutuhkan janin untuk proses pembentukan jaringan dan organ tubuh. ${ }^{24}$ Glukosa juga merupakan salah satu nutrien penting dalam pertumbuhan janin, produksi gula darah fetus yang sangat minim, membuat janin bergantung sepenuhnya kepada suplai glukosa dari sirkulasi maternal melalui plasenta. ${ }^{25}$

Kadar gula darah rendah selama kehamilan dapat menyebabkan peningkatan insiden 
neonatus dengan Small for Gestational Age (SGA). ${ }^{26}$ GLUT 1 (SLC2A1) dipercaya sebagai transporter utama glukosa di plasenta manusia, dan ekspresinya meningkat seiring kehamilan. IGF-1 dapat mempengaruhi ekspresi GLUT 1 sehingga meningkatkan ambilan glukosa yang berguna untuk pertumbuhan janin. ${ }^{14}$

Korelasi IGF-1 Serum Maternal dengan Panjang Badan Lahir Bayi

Hasil uji statistik menunjukkan bahwa terdapat hubungan positif yang lemah dan tidak signifikan antara kadar IGF-1 serum maternal dengan panjang badan lahir bayi ( $p=0,105 ; r=0,260$ dan $\left.R^{2}=0,057\right)$, dengan demikian dapat diartikan bahwa IGF-1 maternal sangat sedikit sekali berkontribusi terhadap panjang badan lahir yakni sebesar 5,7\%, sedangkan 94,3\% sisanya dipengaruhi oleh faktor lain yang tidak diteliti.

Hasil penelitian ini sejalan dengan penelitian yang dilakukan oleh Chiesa dkk. (2008) di Roma yang tidak menemukan tidak adanya hubungan antara kadar IGF-1 maternal dengan panjang badan lahir. Hal ini sama juga dilaporkan oleh Asvold dkk. (2011) di Norwegia dan Pathmaperuma dkk. (2007) di Denmark bahwa tidak terdapat hubungan antara kadar IGF-1 maternal dengan panjang badan lahir bayi. ${ }^{20,27,28}$

Hasil yang berbeda dilaporkan oleh Mclntyre dkk. (2000) yang mendapatkan hubungan antara IGF-1 maternal dengan panjang badan lahir bayi dengan nilai $r=0,51$ dan $p=0,001$. Perbedaan hasil penelitian diduga disebabkan karena perbedaan karakteristik subjek penelitian. Mclntyre dkk. (2000) melibatkan ibu hamil dengan diabetes dan IUGR dalam penelitiannya. ${ }^{29}$

Pada IUGR, terjadi penurunan produksi hormon PGH yang merupakan regulator IGF-1, sehingga kadar IGF-1 maternal menjadi lebih rendah, sedangkan pada kasus diabetes terjadi perubahan produksi sitokin, hormon dan faktor pertumbuhan di plasenta yang disekresikan ke sirkulasi ibu maupun janin. ${ }^{29}$ Diabetes dapat mempengaruhi aksis IGF-1, dimana resistensi insulin dan hiperglikemia dapat menurunkan konsentrasi IGFBP yang merupakan inhibitor aksi IGF-1 dengan demikian dapat meningkatkan bioavailabilitas IGF-1. ${ }^{30}$

Di samping IGFBP, Diabetes juga dapat mempengaruhi reseptor IGF-1 (IGF-1R), sehingga dapat mempengaruhi aktivitas IGF-1. ${ }^{31}$ Penurunan kadar protein IGF-1R juga diikuti oleh gangguan aktivasi molekul persinyalan intrasel sehingga masalah IUGR dapat terjadi. ${ }^{32}$

Masih terdapat kontroversi terkait peran IGF-1 terhadap pertumbuhan janin, karena IGF-1 maternal tidak melintasi plasenta. ${ }^{17}$ Mekanisme bagaimana IGF-1 mempengaruhi pertumbuhan janin kemungkinan besar melalui stimulasi fungsi plasenta dan meningkatkan suplai nutrisi bagi janin. ${ }^{16}$

Tidak ditemukannya korelasi antara IGF-1 maternal dengan panjang badan dapat disebabkan karena terdapat faktor lain 
yang lebih berperan terhadap pertumbuhan janin baik faktor ibu, plasenta maupun faktor janin. Panjang badan bayi baru lahir dapat dipengaruhi oleh tinggi badan ibu, dimana Gen maternal memiliki pengaruh spesifik terhadap pertumbuhan janin. ${ }^{33}$

\section{SIMPULAN}

Terdapat hubungan positif yang signifikan antara kadar IGF-1 maternal dengan berat badan bayi baru lahir, artinya semakin tinggi kadar IGF-1 maternal semakin besar berat badan bayi yang dilahirkan. Namun tidak terdapat hubungan antara kadar IGF1 maternal dengan panjang badan bayi baru lahir.

\section{DAFTAR PUSTAKA}

1. Soltani H, Lipoeto NI, Fair FJ, Kliner K, Yusrawati Y. Pre-pregnancy body mass index and gestational weight gain and their effects on pregnancy and birth outcomes: a cohort study in West Sumatra, Indonesia. BMC Womens Health. 2017; 17(1):102. doi: 10.1186/s12905-017-0455-2. [PubMed].

2. Robson SE, Waugh J, editors. Patologi pada kehamilan, Manajemen dan Asuhan Kebidanan. Jakarta: EGC; 2012.

3. Abu-Saad K, Fraser D. Maternal nutrition and birth outcomes. Epidemiol Rev. 2010; 32:5-25. doi: 10.1093/epirev/mxq001. [PubMed].

4. Badan Penelitian dan Pengembangan Kesehatan Kementerian Kesehatan RI. Riset Kesehatan Dasar (Riskesdas). Jakarta: Kementerian Kesehatan RI; 2013. Diunduh dari: [Link].

5. Dinas Kesehatan Kota Padang. Data jumlah ibu hamil KEK Kota Padang. Padang: Dinas Kesehatan Kota Padang; 2017. Diunduh dari: [Link].

6. Dinas Kesehatan Kota Padang. Data jumlah bayi dengan BBLR Kota Padang. Padang: Dinas Kesehatan Kota Padang; 2014. Diunduh dari: [Link].

7. Kementerian Kesehatan RI. Pedoman Penanggulangan Kurang Energi Kronis (KEK) pada Ibu Hamil. Jakarta: Direktorat Bina Gizi dan Kesehatan Ibu dan Anak; 2015. Diunduh dari: [Link].

8. Dewey KG, Begum K. Insight: Why stunting matter?. A\&T Technical Brief. 2010; 2:1-6. Diunduh dari: [Link].

9. Gibney MJ, Margaretts BM, Kearney JM, Arab L. Gizi Kesehatan Masyarakat. Jakarta: EGC; 2011.

10. Greenstein B, Wood DF. At a Glance System Endokrin. Jakarta: Erlangga; 2007.

11. Aguirre GA, De Ita JR, de la Garza RG, Castilla-Cortazar I. Insulin-like growth factor-1 deficiency and metabolic syndrome. J Transl Med. 2016; 14:3. doi: 10.1186/s12967-015-0762-z. [PubMed].

12. Ameri, $P$, Giusti A, Boschettti M, Murialdo G, Minuto F, Ferone D. Interaction between vitamin D and IGF-1: from physiology to clinical practice. Clin Endocrinol (Oxf). 2013; 79(4):457-63. doi: 10.1111/cen.12268. [PubMed].

13. Jansson T, Powell TL. Role of placental nutrient sensing in developmental programming. Clin Obstet Gynecol. 2013; 56(3):591-601. doi: 10.1097/GRF.0b013e3182993a2e. [PubMed]. 
14. Brett KE, Ferraro ZM, Yockell-Lelievre J, Gruslin A, Adamo KB. Maternal-fetal nutrient transport in pregnancy pathologies: the role of the placenta. Int J Mol Sci. 2014; 15(9):16153-85. doi: 10.3390/ijms150916153. [PubMed].

15. Sferuzzi-Perri A, Owens J, Peringle K, Robets C (2011). The neglected role of insulin-like growth factors in the maternal circulation regulating fetal growth. J Physiol. 2011; 589(Pt 1):7-20. doi: 10.1113/jphysiol.2010.198622. [PMC free article].

16. Karamizadeh Z, Saki S, Kashef S, Saki F. Comparison of Umbilical Cord and Maternal Serum Levels of IGF-1, Leptin and Cortisol in Appropriate for Gestational Age and Small for Gestational Age Neonates. Int J Endocrinol Metab. 2008; 6(2): 89-94. [Abstract/Free Full-Text].

17. Lima RV, Neto DG, de Mattos Segre CA, Goldenberg S. Insulin-like growth factor-I and its binding proteins in healthymothers and their newborns. Einstein. 2004; 2(2):105-9. [Abstract/Free FullText].

18. Kementerian Kesehatan RI. Profil Kesehatan Kota Padang, Angka kejadian KEK pada ibu hamil tahun 2016. Jakarta: Kementerian Kesehatan RI; 2017. Diunduh dari: [Link].

19. Dahlan MS. Besar sampel dan cara pengambilan sampel dalam penelitian kedokteran dan kesehatan. Edisi Ke-4. Jakarta: Salemba Medika; 2011.

20. Åsvold BO, Eskild A, Jenum PA, Vatten L. Maternal concentrations of insulin-like growth factor I and insulin-like growth factor binding protein 1 during pregnancy and birth weight of offspring. Am J Epidemiol. 2011; 174(2):129-35. doi: 10.1093/aje/kwr067. [PubMed].

21. Chellakooty M, Vangsgaard K, Larsen T, Scheike T, Falck-Larsen J, Legarth J, et al. A longitudinal study of intrauterine growth and the placental growth hormone $(\mathrm{GH})$-insulin-like growth factor I axis in maternal circulation: association between placental GH and fetal growth. J Clin Endocrinol Metabolism. 2004; 89(1):384-91. doi: 10.1210/jc.2003-030282. [PubMed].

22. Jansson N, Nilsfelt A, Gellerstedt $M$, Wennergren $M$, Rossander-Hulthén $L$, Powell $T L$, et al. Maternal hormones linking maternal body mass index and dietary intake to birth weight. Am J Clin Nutr. 2008; 87(6):1743-9. doi: 10.1093/ajcn/87.6.1743. [PubMed].

23. Haram K, Søfteland E, Bukowski R. Intrauterine Growth Restriction: Effects of Physiological Fetal Growth Determinants on Diagnosis. Obstet Gynecol Int. 2013; 2013:708126. doi: 10.1155/2013/708126. [PMC free article].

24. Kavitha JV, Rosario FJ, Nijland MJ, McDonald TJ, Wu G, Kanai Y, et al. Down-regulation of placental mTOR, insulin/IGF-I signaling, and nutrient transporters in response to maternal nutrient restriction in the baboon. FASEB J. 2014; 28(3):1294-305. doi: 10.1096/fj.13-242271. [PubMed].

25. Lager S, Powell TL. Regulation of nutrient transport across the placenta. J Pregnancy. 2012; 2012:179827. doi: 10.1155/2012/179827. [PubMed].

26. Leguizamón G, von Stecher F. Third trimester glycemic profiles and fetal growth. Curr Diab Rep. 2003; 3(4):323-6. [PubMed].

27. Chiesa C, Osborn JF, Haass C, Natale F, Spinelli M, Scapillati E, et al. Ghrelin, leptin, IGF-1, IGFBP3 , and insulin concentrations at birth: is there a relationship with fetal growth and neonatal anthropometry?. Clin Chem. 2008; 54(3):550-8. doi: 10.1373/clinchem.2007.095299. [PubMed].

28. Pathmaperuma AN, Tennekoon KH, Senanayake L, Karunanayake EH. Maternal and cord blood levels of insulin-like growth factors--I and--II and insulin-like growth factor binding protein-1: 
correlation with birth weight and maternal anthropometric indices. Ceylon Med J. 2007; 52(2):4852. [PubMed].

29. McIntyre HD, Serek R, Crane DI, Veveris-Lowe T, Parry A, Johnson S, et al. Placental growth hormone (GH), GH-binding protein, and insulin-like growth factor axis in normal, growth-retarded, and diabetic pregnancies: correlations with fetal growth. J Clin Endocrinol Metab. 2000; 85(3):1143-50. doi: 10.1210/jcem.85.3.6480. [PubMed].

30. Hiden U1, Glitzner E, Hartmann M, Desoye G. Insulin and the IGF system in the human placenta of normal and diabetic pregnancies. J Anat. 2009; 215(1):60-8. doi: 10.1111/j.14697580.2008.01035.x. [PubMed].

31. Forbes K, Westwood M. The IGF axis and placental function, a mini review. Horm Res. 2008; 69(3):129-37. doi: 10.1159/000112585. [PubMed].

32. Kappou D, Vrachnis N, Sifakis S. Recent Insights into the Role of the Insulin-Like Growth Factor Axis in Preeclampsia. In: From Preconception to Postpartum. Rijeka: Intech; 2012. p.147-60. doi: $10.5772 / 37881$.

33. Pomeroy E, Wells JC, Cole TJ, O'Callaghan M, Stock JT. Relationships of maternal and paternal anthropometry with neonatal body size, proportions and adiposity in an Australian cohort. Am J Phys Anthropol. 2015; 156(4):625-36. doi: 10.1002/ajpa.22680. [PubMed]. 